\title{
Manipulation of MWCNT Concentration in MWCNT/TiO Nanocomposite Thin Films for Dye-Sensitized Solar Cell
}

\author{
Huda Abdullah, ${ }^{1}$ Mohd Zikri Razali, ${ }^{1}$ Sahbudin Shaari, ${ }^{2}$ and Mohd Raihan Taha ${ }^{3}$ \\ ${ }^{1}$ Department of Electrical, Electronic \& System, Faculty of Engineering and Built Environment, Universiti Kebangsaan Malaysia, \\ 43600 Bangi, Selangor, Malaysia \\ ${ }^{2}$ Institute of Microengineering and Nanoelectronics (IMEN), Universiti Kebangsaan Malaysia, 43600 Bangi, Selangor, Malaysia \\ ${ }^{3}$ Department of Civil and Structural Engineering, Faculty of Engineering and Built Environment, Universiti Kebangsaan Malaysia, \\ 43600 Bangi, Selangor, Malaysia \\ Correspondence should be addressed to Huda Abdullah; huda@eng.ukm.my
}

Received 28 December 2013; Accepted 13 January 2014; Published 24 February 2014

Academic Editor: Jiaguo Yu

Copyright ( 2014 Huda Abdullah et al. This is an open access article distributed under the Creative Commons Attribution License, which permits unrestricted use, distribution, and reproduction in any medium, provided the original work is properly cited.

\begin{abstract}
Dye-sensitized solar cell (DSSC) using multiwalled carbon nanotube/titanium dioxide $\left(\mathrm{MWCNT}_{\mathrm{TiO}}\right)$ ) was successfully synthesized using sol-gel method. In this method, it has been performed under various acid treatments MWCNT concentration level at (a) $0.00 \mathrm{~g}$, (b) $0.01 \mathrm{~g}$, (c) $0.02 \mathrm{~g}$, and (d) $0.03 \mathrm{~g}$. Atomic force microscopy (AFM) was used to study surface roughness of the $\mathrm{MWCNT} / \mathrm{TiO}_{2}$ thin films. The average roughness results for $0.00 \mathrm{~g}, 0.01 \mathrm{~g}, 0.02 \mathrm{~g}$, and $0.03 \mathrm{~g}$ were 10.995, 18.308, 24.322, and $25.723 \mathrm{~nm}$, respectively. High resolution transmission electron microscopy (HR-TEM) analysis showned the inner structural design of the $\mathrm{MWCNT} / \mathrm{TiO}_{2}$ particles. The $\mathrm{TiO}_{2}$ nanoparticles covered almost all the area of MWCNT particles. Field emission scanning electron microscopy (FESEM) gave the morphological surface structure of the thin films. The thin films formed in good distribution with homogenous design. The DSSC with $\mathrm{MWCNT} / \mathrm{TiO}_{2}$ electrode containing $0.03 \mathrm{~g} \mathrm{MWCNT}$ were resulted in the highest efficiency of $2.80 \%$ with short-circuit current density $\left(J_{\text {sc }}\right)$ of $9.42 \mathrm{~mA} / \mathrm{cm}^{2}$ and open-circuit voltage $\left(V_{\text {oc }}\right)$ of $0.65 \mathrm{~V}$.
\end{abstract}

\section{Introduction}

Dye-sensitized solar cell (DSSC) is considered as a relatively new type of solar cell being discovered, in 1991, by Grätzel et al. DSSC shows greater promise compared to $\mathrm{Si}$ solar cells due to low cost, environmental friendly and simple manufacturing process. DSSC has attracted a lot of attention worldwide. Nevertheless, Grätzel's cell has a solar conversion efficiency of $\sim 13 \%$ [1], which is significantly lower than that of Si solar cells. To improve the performance of DSSC devices, a number of aspects are considered. Electron transport across a $\mathrm{TiO}_{2}$ electrode is one of the most important factors affecting the conversion efficiency of DSSC; the greater electron mobility is, the higher the DSSC efficiency will be [2]. On the other hand, charge recombination processes generally inhibited injected electrons from $\mathrm{TiO}_{2}$ to the conducting glass substrate, thus decreasing the performance of DSSC. Therefore, the rapid photo induced electron transport in the working electrode, $\mathrm{TiO}_{2}$, and the suppression of charge recombination processes can ensure a higher conversion efficiency of DSSC $[3,4]$.

In recent years, multiwalled carbon nanotube MWCNT has attracted considerable attention worldwide due to its excellent mechanical properties and electrical and thermal conductivity making it a high potential candidate in various applications, for example, field emission display [5], photo catalysis, photovoltaic devices, and DSSC [6]. Several researches $[7,8]$ reported the incorporation of MWCNT within nanocrystalline $\mathrm{TiO}_{2}$ working electrodes to enhance the solar energy conversion efficiency of DSSC. Furthermore, some studies [9] have revealed that the better performance of DSSC fabricated using $\mathrm{MWCNT} / \mathrm{TiO}_{2}$ electrodes is because of the higher electron mobility at the electrodes than that of conventional $\mathrm{TiO}_{2}$ electrodes. This resulted in a higher short-circuit photocurrent $\left(J_{\text {sc }}\right)$ of DSSC. However, the performance of DSSC dropped when high MWCNT content 
was applied to the $\mathrm{MWCNT} / \mathrm{TiO}_{2}$ electrode, possibly due to a severe aggregation of MWCNT in the nanocomposite electrode $[10,11]$.

In this study, we aim to synthesize and fabricate $\mathrm{MWCNT} / \mathrm{TiO}_{2}$ dye-sensitized solar cell using sol-gel method with different concentrations of MWCNT. The different MWCNT concentrations were the main key in order to get better photovoltaic efficiency. We investigate the MWCNT concentration effect on the solar cell in terms of their photo-conversion efficiency performance. The samples were analyzed using FESEM, TEM, AFM, and IV curve analysis to see the effect of MWCNT doped into $\mathrm{TiO}_{2}$ photoelectrode.

\section{Methodology}

2.1. Materials. Titanium (IV) tetraisopropoxide (TTIP) (98\%) was purchased from Sigma-Aldrich, Belgium, and used as the main material. MWCNT, $98 \%$ carbon basis with length of 6 to $13 \mathrm{~nm}$, was purchased from Sigma-Aldrich, USA. The MWCNT will go through the acid treatment process before being used. The MWCNT will be sonicated for $2 \mathrm{~h}$ in a beaker containing $50 \mathrm{~mL}$ of concentrated nitric acid and boiled at $90^{\circ} \mathrm{C}$ on a hotplate. The MWCNT powder achieved after filtering was washed several times using distilled water to remove residual acid and dried in oven for $24 \mathrm{~h}$. In this study, other chemicals were used as ethanol anhydrous $I_{2}$ (99.5\%), ruthenium 620-1H3TBA dye obtained from Solaronix SA, adult MPN-100 purchased from Solaronix SA, nitric acid (95\%), and electrode substrate fluorine tin oxide (FTO) glasses, $30 \Omega$, obtained from Solaronix SA and used as received.

2.2. Preparation of $M W C N T / T i O_{2}$ Solution. $\mathrm{TiO}_{2}$ nanoparticles are produced from titanium (IV) tetraisopropoxide that acts as a precursor solution. The TTIP solution mixed with anhydrous ethanol solution in the ratio of $(0.1 / 2)$ using magnetic bar stirrer for $30 \mathrm{~min}$. The acid treatment MWCNT powder with different weights of (a) $0.00 \mathrm{~g}$, (b) $0.01 \mathrm{~g}$, (c) $0.02 \mathrm{~g}$, and (d) $0.03 \mathrm{~g}$ was added into the $\mathrm{TiO}_{2}$ colloidal solution paste and dispersed using an ultrasonic horn machine for $60 \mathrm{~min}$. $\mathrm{MWCNT} / \mathrm{TiO}_{2}$ nanocomposite stirred vigorously for another $2 \mathrm{~h}$ to get homogeneous solution. The MWCNT/ $/ \mathrm{TiO}_{2}$ paste coated onto the fluorine tin oxide (FTO) conductive glass using doctor-blade technique to generate $0.25 \mathrm{~cm}^{2}$ active area is followed by evaporation of ethanol in air at room temperature for a few minutes. All the MWCNT/ $/ \mathrm{TiO}_{2}$ thin films were annealed in a dry furnace at $300^{\circ} \mathrm{C}$ for $30 \mathrm{~min}$ forming noncrack and uniform thin film electrode. Figure 1 shows the flowchart of this preparation.

2.3. Fabrication of Dye-Sensitized Solar Cell. The annealed $\mathrm{MWCNT} / \mathrm{TiO}_{2}$ electrode thin films were then being immersed in $0.5 \mathrm{M}$ N719 ruthenium dye for 1 day to make sure that all the $\mathrm{MWCNT} / \mathrm{TiO}_{2}$ particles were covered with the N719 dye particle. The electrodes were then sandwiched with another electrode glass called counter electrode which was covered with platinum $(\mathrm{Pt})$ thin film on top of the FTO glass. Both electrodes separated using parafilm barrier

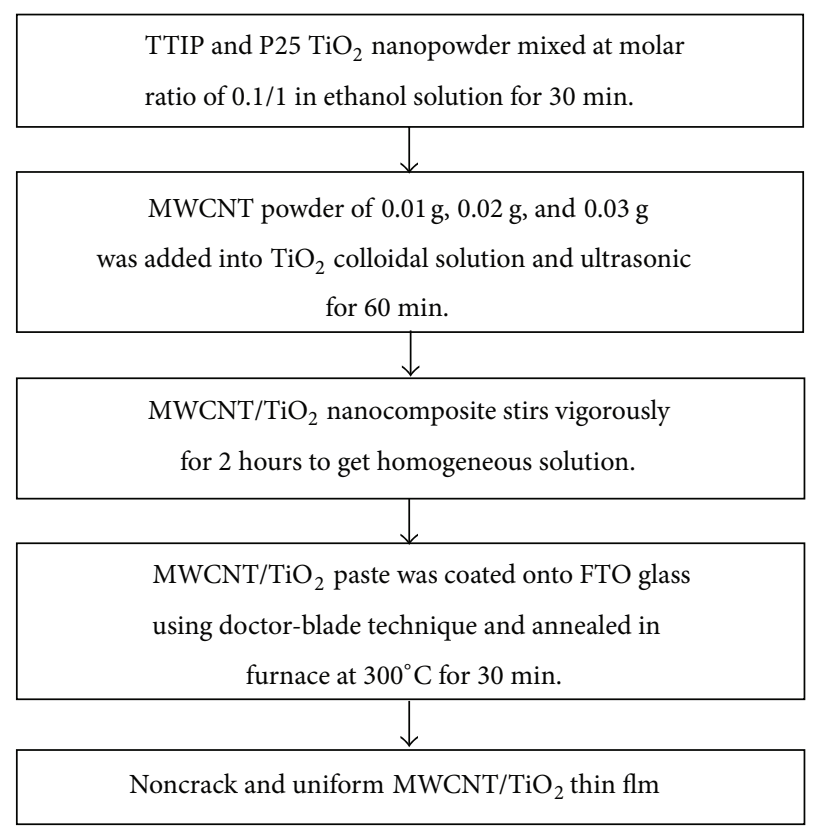

FIGURE 1: Flowchart diagram for synthesis $\mathrm{MWCNT}_{\mathrm{TiO}}$ nanocomposite thin film.

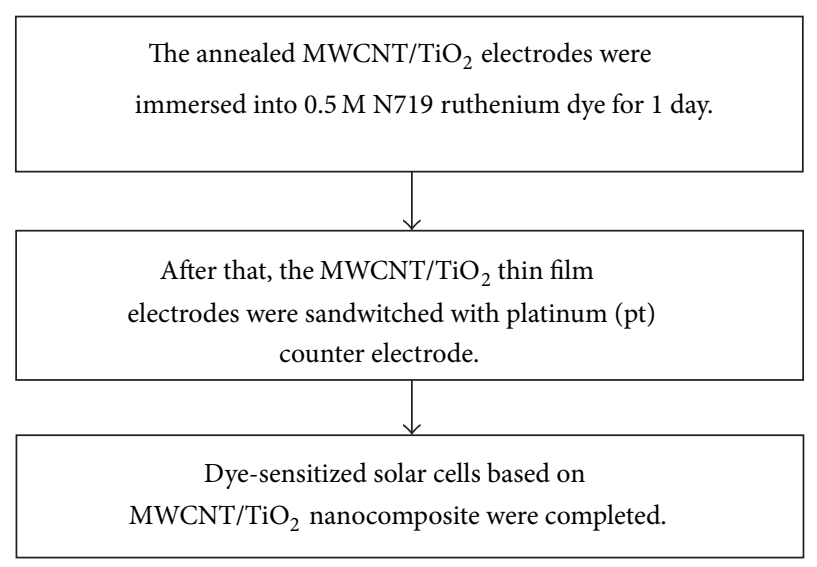

FIGURE 2: Flowchart diagram for fabrication of $\mathrm{MWCNT} \mathrm{TiO}_{2}$ dyesensitized solar cell.

to place electrolyte between the electrodes. DSSC based $\mathrm{MWCNT} / \mathrm{TiO}_{2}$ nanocomposite is completed and is ready to be analyzed. Figure 2 shows the flowchart of this preparation.

2.4. Characterization. Field emission scanning electron microscopy (FESEM, Zeisz Supra-15KV) was used to analyze the morphological structure of the MWCNT/TiO 2 thin film. Transmission electron microscopy (TEM, CM12 Philips, $1990)$ is a device used to see the internal structure of a sample. This microscopy has expanded until 660,000x with resolution around $100 \mathrm{~nm}$ at $120 \mathrm{keV}$. Atomic force microscopy (AFM) analysis showed the roughness of thin film in 3D images. Photovoltaic analysis (GAMRY Instruments G300) was assessed as simulated AM 1.5 xenon illumination with 


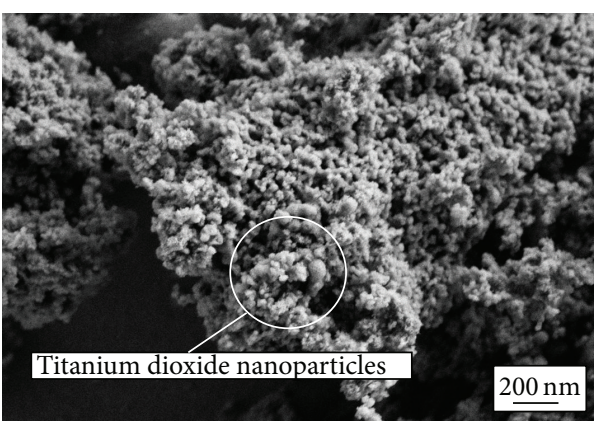

(a)

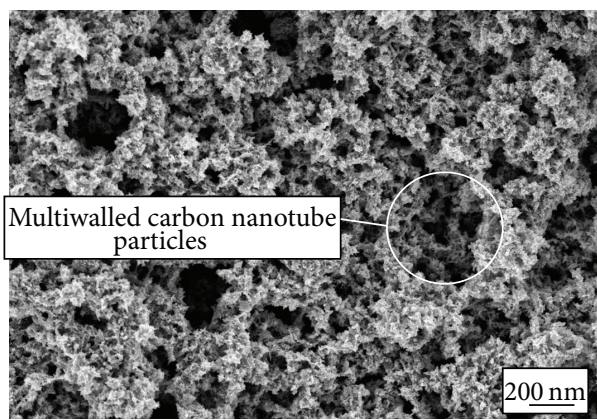

(c)

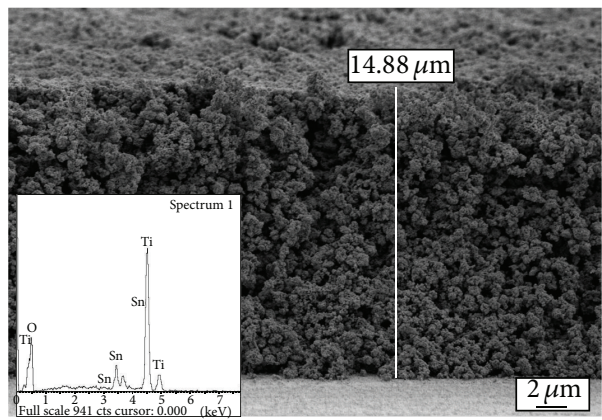

(e)

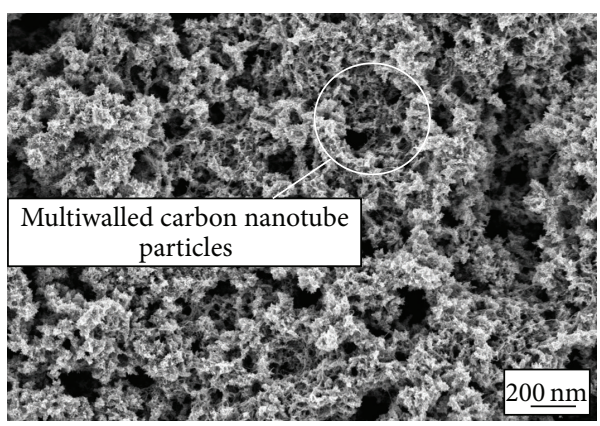

(b)

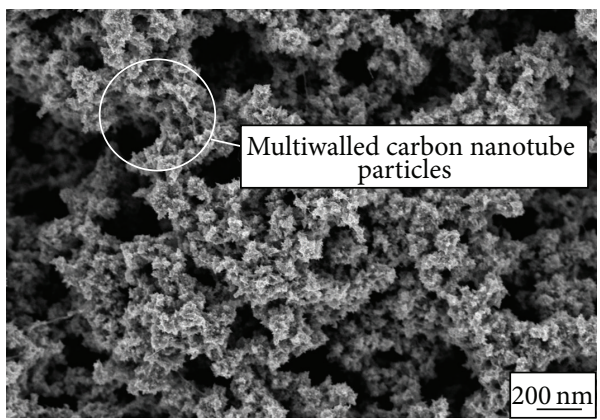

(d)

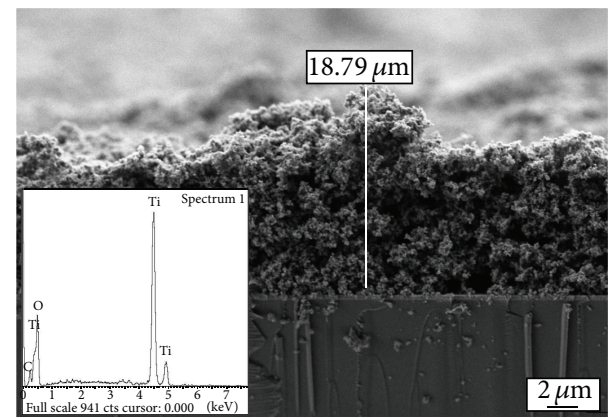

(f)

Figure 3: The FESEM images of undoped (a) $0.00 \mathrm{~g}$, (b) $0.01 \mathrm{~g}$, (c) $0.02 \mathrm{~g}$, and (d) $0.03 \mathrm{~g}$ added MWCNT; while image (e) and (f) show the average thickness of the thin films with EDX graph.

a $100 \mathrm{~mW} / \mathrm{cm}^{2}$ light output. All experimental results were characterised by good repeatability.

\section{Results and Discussions}

3.1. Field Emission Scanning Electron Microscopy (FESEM). By referring to other researches and studies [12], we expect to improve the solar cell energy conversion efficiency with the presence of the MWCNT as favorable electrical conductivity on the metal oxide nanocomposite. MWCNT nanoparticles can extend the electron lifetime and enhance the electron transport rate in the photovoltaic metal oxide electrode. In addition, we notice that the MWCNT nanoparticles that go through acid treatment process in the concentrated nitric acid could produce MWCNT with terminal COOH group. This phenomenon can improve the solar cell electron collection due to better interconnection between MWCNT and $\mathrm{TiO}_{2}$ nanoparticles.

Figure 3: (a) $0.00 \mathrm{~g}$, (b) $0.01 \mathrm{~g}$, (c) $0.02 \mathrm{~g}$, and (d) $0.03 \mathrm{~g}$ show the morphological images of $\mathrm{MWCNT} / \mathrm{TiO}_{2}$ thin films, where else for (e) and (f) images show the film cross-section and EDX graph. From FESEM images, we found that the MWCNT and $\mathrm{TiO}_{2}$ nanoparticles there are in good contact. MWCNT nanoparticles are well dispersed and highly compact after annealing at $300^{\circ} \mathrm{C}$ for $30 \mathrm{~min}$. The porosity can be observed from the morphological structure of all thin films. The thin films are connected randomly which in lack dissemble long range order for the pore arrangement. We also found that, with every additional MWCNT, the porosity of the thin film became bigger and larger, while the $\mathrm{TiO}_{2}$ nanoparticles become smaller and thinner $[13,14]$. The thin films also show, with increasing the amount of MWCNT, the structural morphology of $\mathrm{TiO}_{2}$ nanoparticles changes from spherical 
TABLE 1: Weight percentage parameter from EDX analysis.

\begin{tabular}{lcccc}
\hline Sample & MWCNT added & Carbon (\%) & Oxygen (\%) & Titanium (\%) \\
\hline (a) & $\mathrm{TiO}_{2}-$ nanoparticles & 0.00 & 40.09 & 59.91 \\
(b) & ${\mathrm{MWCNT} / \mathrm{TiO}_{2}-0.01 \mathrm{~g}}$ & 4.15 & 40.14 & 55.71 \\
(c) & $\mathrm{MWCNT} / \mathrm{TiO}_{2}-0.02 \mathrm{~g}$ & 5.25 & 39.64 & 55.11 \\
(d) & ${\mathrm{MWCNT} / \mathrm{TiO}_{2}-0.03 \mathrm{~g}}$ & 6.55 & 38.84 & 54.61 \\
\hline
\end{tabular}

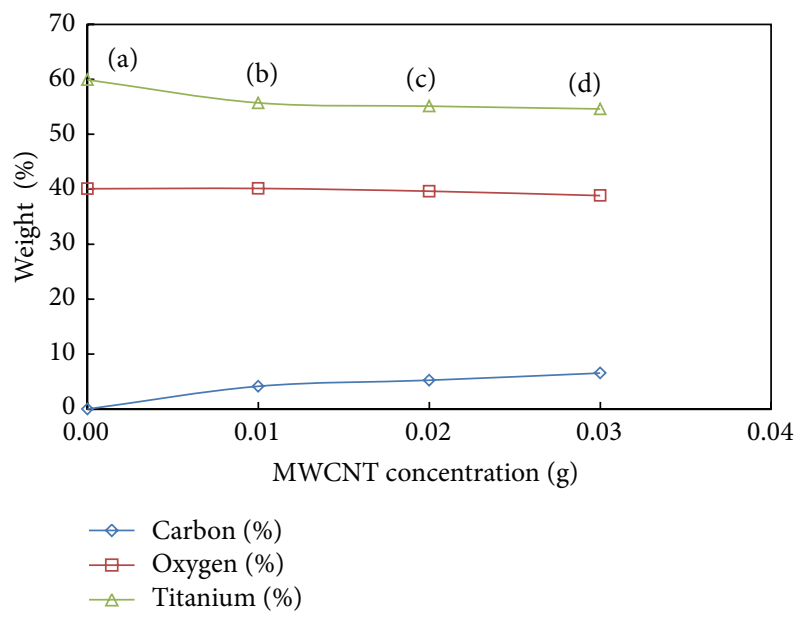

FIGURE 4: Carbon weight percentage graph from EDX spectroscopy analysis.

to oval nanoparticles structure, which existed around the long range MWCNT nanoparticles. The average thickness of $\mathrm{TiO}_{2}$ and $\mathrm{MWCNT} / \mathrm{TiO}_{2}$ thin film samples around $14.88 \mu \mathrm{m}$ and $18.79 \mu \mathrm{m}$, respectively. The addition of MWCNT can improve the structural and morphological design of the films. However, the amount of MWCNT added must be controlled and optimized to produce high quality electrode thin film. The amount of MWCNT can affect the films in terms of large crack and inhomogeneous arrangement. Referring to others [15], with the increase in the amount of MWCNT, the number of cracks on the surface of the films is increased subsequently. It is thought that the cracks generated on the surface could be reducing the number of adsorption sites on $\mathrm{TiO}_{2}$ film as well as causing the discrimination in the conversion efficiency of DSSC.

Table 1 shows the data collected for energy dispersive Xray (EDX) spectroscopy analysis. The EDX data prove that every additional MWCNT added into the samples, the carbon weight percentage in the samples increased from $0.00 \%$, $4.15 \%$, and $2.25 \%$ to $6.55 \%$ of samples (a) $0.00 \mathrm{~g}$, (b) $0.01 \mathrm{~g}$, (c) $0.02 \mathrm{~g}$, and (d) $0.03 \mathrm{~g}$, respectively. These results confirm that the sample (d) $0.03 \mathrm{~g}$ MWCNT added has a larger MWCNT weight percentage compared to the other samples. Figure 4 shows the MWCNT weight percentage in graphical diagram. Both oxygen and titanium compound weight percentage data were decreased in small amounts from $40.09 \%$ to $38.84 \%$ and from $59.91 \%$ to $54.61 \%$, correspondingly.
TABLE 2: Average length of $\mathrm{MWCNT} / \mathrm{TiO}_{2}$ nanocomposite and $\mathrm{TiO}_{2}$ nanoparticles parameter.

\begin{tabular}{lc}
\hline Type & Size/nm \\
\hline MWCNT inner structure & 4.49 \\
MWCNT outer structure & 17.71 \\
$\mathrm{TiO}_{2}$ attached at MWCNT & 3.91 \\
$\mathrm{TiO}_{2}$ nanoparticles & 12.00 \\
\hline
\end{tabular}

3.2. High Resolution Transmission Electron Microscopy (HRTEM). In Figure 5, the HR-TEM images of $\mathrm{TiO}_{2}$ nanoparticles (a) $0.00 \mathrm{~g}$, (b) $0.01 \mathrm{~g}$ (c) $0.02 \mathrm{~g}$, and (d) $0.03 \mathrm{~g}$ MWCNT/TiO 2 nanocomposite are shown. Images in Figures 5(a), 5(b), 5(c), and 5(d) are carried out to show the comparison between undoped $\mathrm{TiO}_{2}$ nanoparticles and $\mathrm{TiO}_{2}$ doped MWCNT nanocomposite in terms of their inner structure design. HR-TEM investigation on selected MWCNT partially covered by $\mathrm{TiO}_{2}$ aggregates indicates that simple or multiple connections of aggregates of $\mathrm{TiO}_{2}$ nanoparticles to MWCNT are possible. In Figure $3(\mathrm{a}), \mathrm{TiO}_{2}$ nanoparticles with low grain density and compact agglomerate configuration were observed. The $\mathrm{TiO}_{2}$ nanoparticles sizes vary compared to the $\mathrm{TiO}_{2}$ attached to MWCNT particles. From images (b, c, and $\mathrm{d}$ ), by using chemical treatment process, we can see the MWCNT particles successfully formed in nanotube structure. From these images, we can find out that the type of CNT used in this research is MWCNT not SWCNT $[16,17]$. This can be confirmed by the multiple thin walls formed along the CNT. The $\mathrm{TiO}_{2}$ nanoparticles and $\mathrm{TiO}_{2}$ sphere-like shape are formed and positioned mostly around the MWCNT particles. Another researcher [18] also implies that there is a good contact between MWCNTs and $\mathrm{TiO}_{2}$ particles. MWCNTs are directly coupled with the uniform anatase shell, which are together embedded in the $\mathrm{TiO}_{2}$ aggregates. Such a structural feature is beneficial for efficient electron transfer and hole-electron separation, as if there is a "conducting wire" acting as a readily accessible electrontransfer channel.

Table 2 illustrates the data size parameter for $\mathrm{TiO}_{2}$ doped MWCNT nanocomposite and $\mathrm{TiO}_{2}$ nanoparticles alone. The MWCNT inner and outer structure diameters were approximately $4.49 \mathrm{~nm}$ and $17.71 \mathrm{~nm}$ in length, respectively. The diameter size for $\mathrm{TiO}_{2}$ doped MWCNT was slightly smaller with only $3.91 \mathrm{~nm}$ compared to the $\mathrm{TiO}_{2}$ nanoparticles with $12.00 \mathrm{~nm}$. This might be due to the combination with MWCNT nanoparticles that reduce the $\mathrm{TiO}_{2}$ size and hence produce highly porous thin film as presented and shown in 


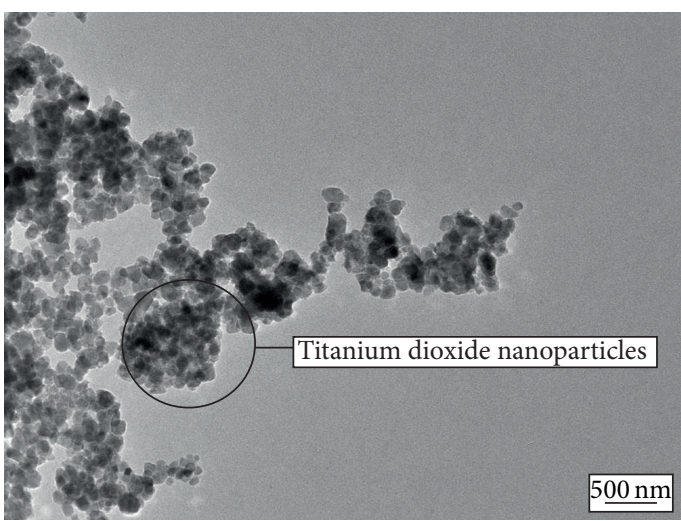

(a)

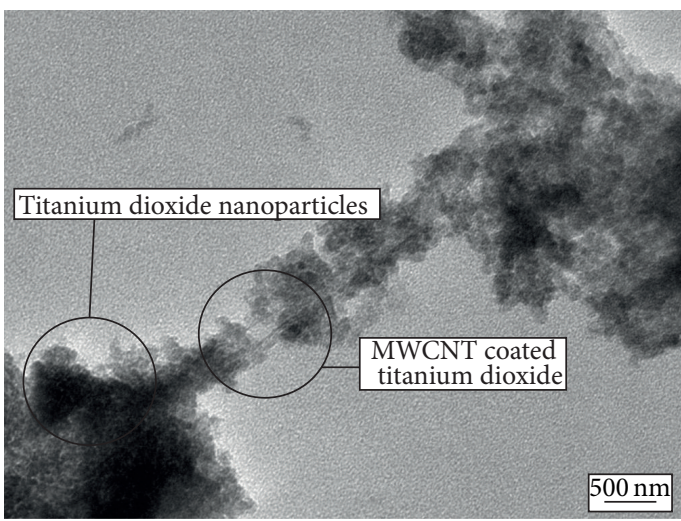

(c)

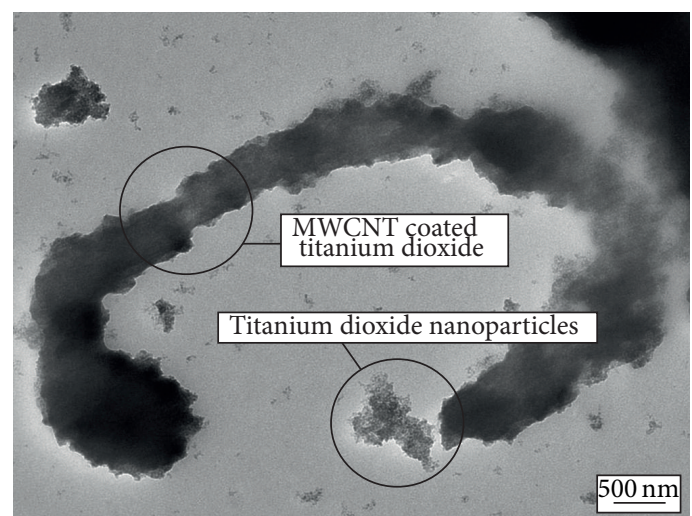

(b)

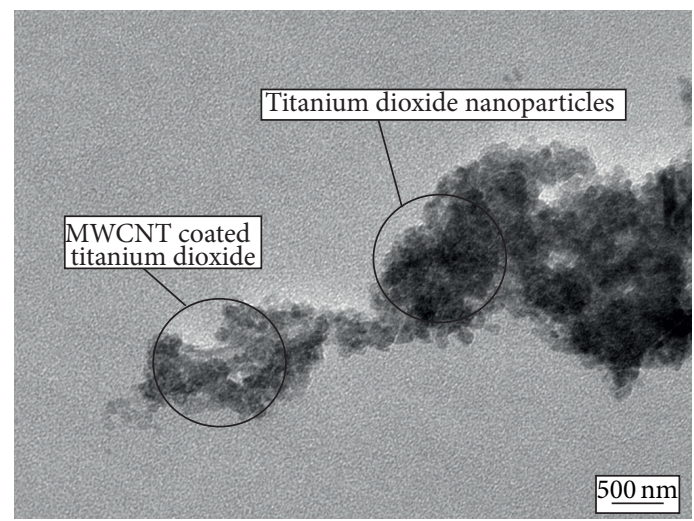

(d)

FIGURE 5: HR-TEM images of undoped (a) $0.00 \mathrm{~g}$, (b) $0.01 \mathrm{~g}$, (c) $0.02 \mathrm{~g}$, and (d) $0.03 \mathrm{~g} \mathrm{MWCNT}^{\mathrm{T}} \mathrm{TiO}_{2}$ nanocomposite.

the FESEM analysis. HR-TEM images suggest a good affinity between the $\mathrm{TiO}_{2}$ and the MWCNT, which is important in view of limiting the MWCNT loading required to improve DSSC performance. MWCNT improves the roughness factor of the electrode and limits the charge recombination of electron/hole $\left(\mathrm{e}^{-} / \mathrm{h}^{+}\right)$pairs [19]. Another advantage of combining MWCNT with $\mathrm{TiO}_{2}$ was to get higher photo response due to decrease in resistivity of the thin film and resulting in a higher current collection at the electrode thin film $[20,21]$.

Nevertheless, a high loading of MWCNT causes lightharvesting competition that affects the light absorption of the dye sensitizer and consequently reduces the cell efficiency. Moreover, an excess of MWCNT can result in a less compact $\mathrm{TiO}_{2}$ layer, in which large pores are formed at the micron scale [22] or in the formation of quite disconnected aggregates of MWCNT covered in conformance by $\mathrm{TiO}_{2}$ nanoparticles.

3.3. Atomic Force Microscopy (AFM). The $\mathrm{MWCNT} / \mathrm{TiO}_{2}$ thin films upper texture prepared using doctor-blade technique are observed by AFM instrument. Images in Figure 6: (a) $0.00 \mathrm{~g}$, (b) $0.01 \mathrm{~g}$, (c) $0.02 \mathrm{~g}$, and (d) $0.03 \mathrm{~g}$ demonstrate that, with increasing MWCNT concentration in the $\mathrm{MWCNT} / \mathrm{TiO}_{2}$ sample, the texture of the thin films
TABLE 3: Average roughness parameter for all samples.

\begin{tabular}{lcc}
\hline Sample & MWCNT added & Root mean square $(\mathrm{rms}) / \mathrm{nm}$ \\
\hline (a) & $0.00 \mathrm{~g}$ & 10.995 \\
(b) & $0.01 \mathrm{~g}$ & 18.308 \\
(c) & $0.02 \mathrm{~g}$ & 24.322 \\
(d) & $0.03 \mathrm{~g}$ & 25.723 \\
\hline
\end{tabular}

became rougher and the particle arrangement became compact. This condition can be appointed from the root mean square (rms) value. The AFM analysis results unveil that the nonadded MWCNT $0.00 \mathrm{~g}$ has roughness average value of only $10.995 \mathrm{~nm}$. The roughness average slightly increases with additional MWCNT added with $18.308 \mathrm{~nm}$ for $0.01 \mathrm{~g}$, $24.322 \mathrm{~nm}$ for $0.02 \mathrm{~g}$, and $25.723 \mathrm{~nm}$ for $0.03 \mathrm{~g}$. These image data also reveal that rms value drastically increases for each sample. The rms values of the $\mathrm{MWCNT} / \mathrm{TiO}_{2}$ thin film are listed in Table 3 and the data are illustrated with graphical diagram in Figure 7.

AFM measurement investigates the surface morphological roughness of the film. By AFM roughness analysis, roughness factors obtained are increased as increasing the content of MWCNT in $\mathrm{TiO}_{2}$ film with the maximum value in $0.03 \mathrm{~g}$ carbon-content $\mathrm{TiO}_{2}$ as listed in Table 1. This 


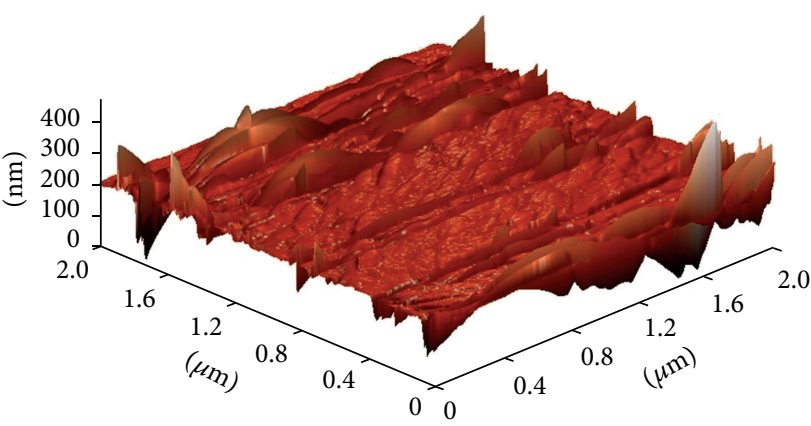

(a)

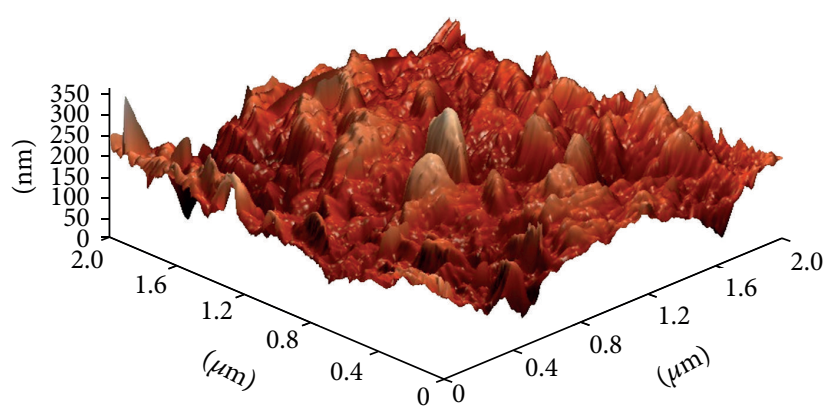

(c)

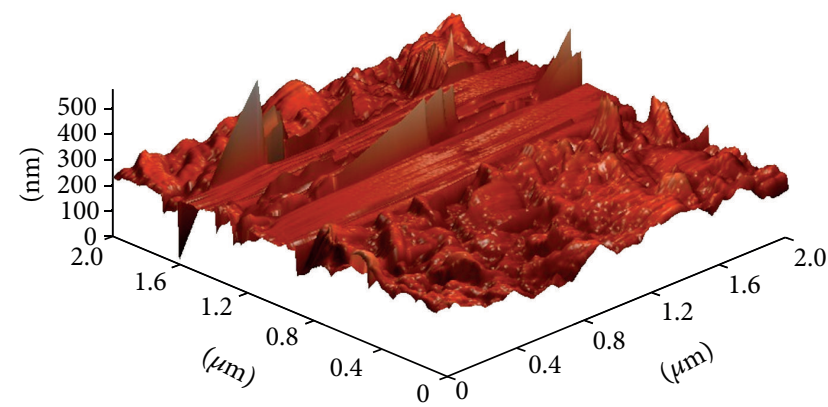

(b)

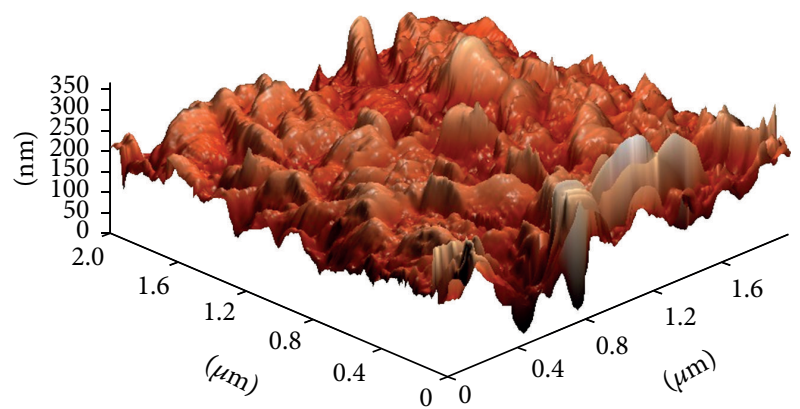

(d)

FIGURE 6: Surface roughness images of $\mathrm{MWCNT} / \mathrm{TiO}_{2}$ thin film with different $\mathrm{MWCNT}$ concentrations of undoped (a) $0.00 \mathrm{~g}$, (b) $0.01 \mathrm{~g}$, (c) $0.02 \mathrm{~g}$, and (d) $0.03 \mathrm{~g}$ added MWCNT.

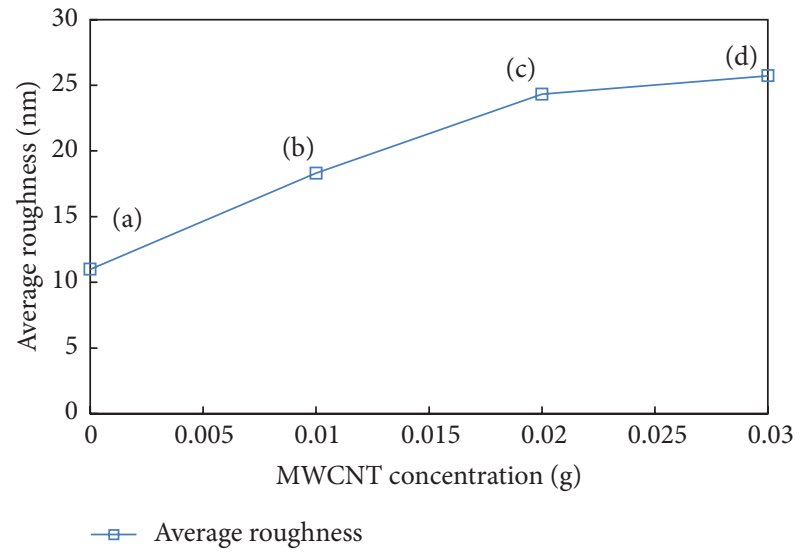

FIGURE 7: Graphical diagram for $\mathrm{MWCNT} / \mathrm{TiO}_{2}$ thin film roughness of undoped (a) $0.00 \mathrm{~g}$, (b) $0.01 \mathrm{~g}$, (c) $0.02 \mathrm{~g}$, and (d) $0.03 \mathrm{~g}$ added MWCNT.

characterization is an important characteristic to investigate the surface reflection phenomenon in DSSC [23]. Due to the increase in roughness average, the enlargement for surface texture angle in the thin film will bounce the light on surface films and causing the light to reflect indirectly back to the electrode surface. This phenomenon can increase the light absorption in the metal oxide photovoltaic and improve the light of electrical conversion energy because the light reflectance had been reduced [24].

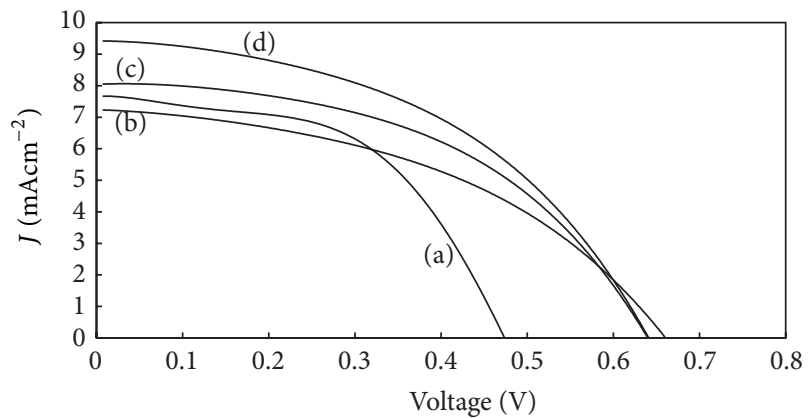
(a) $0.00 \mathrm{~g}$
(c) $0.02 \mathrm{~g}$
(b) $0.01 \mathrm{~g}$
(d) $0.03 \mathrm{~g}$

FIGURE 8: Efficiency percentage graphical diagram for $\mathrm{MWCNT} / \mathrm{TiO}_{2}$ DSSC of undoped (a) $0.00 \mathrm{~g}$, (b) $0.01 \mathrm{~g}$, (c) $0.02 \mathrm{~g}$, and (d) $0.03 \mathrm{~g}$ added MWCNT.

3.4. I-V Curve Efficiency. Figure 8 shows the $I$-V curve graph of $\mathrm{MWCNT} / \mathrm{TiO}_{2}$ thin film photoelectrode dye-sensitized solar cell. This process is performed under $100 \mathrm{~mW} / \mathrm{cm}^{2}$ illuminations using xenon lamp. The measurement of light to electrical process was executed after completing the sandwich-look DSSC between electrode and counter electrode part. The parameters included in Table 4 were opencircuit voltage $\left(V_{\mathrm{oc}}\right)$, short-circuit photocurrent density $\left(J_{\mathrm{sc}}\right)$, fill factor (FF), and energy conversion efficiency $(\eta)$ [25]. As stated in Table 4 , open-circuit voltage $\left(V_{\text {oc }}\right)$ data increased 
TABLE 4: Solar cell efficiency parameter of $\mathrm{MWCNT} / \mathrm{TiO}_{2}$ with different MWCNT concentrations.

\begin{tabular}{|c|c|c|c|c|c|}
\hline Sample & MWCNT added & $V_{\mathrm{oc}} / \mathrm{V}$ & $J_{\mathrm{sc}} / \mathrm{mAcm}^{-2}$ & Fill factor (FF) & $\eta / \%$ \\
\hline (a) & $0.00 \mathrm{~g}$ & 0.49 & 7.60 & 0.38 & 1.43 \\
\hline (b) & $0.01 \mathrm{~g}$ & 0.67 & 7.25 & 0.43 & 2.12 \\
\hline (c) & $0.02 \mathrm{~g}$ & 0.64 & 8.11 & 0.47 & 2.46 \\
\hline (d) & $0.03 \mathrm{~g}$ & 0.65 & 9.42 & 0.45 & 2.80 \\
\hline
\end{tabular}

from $0.49 \mathrm{~V}$ to $0.67 \mathrm{~V}$ but decreased to $0.64 \mathrm{~V}$ for samples (a) $0.00 \mathrm{~g}$, (b) $0.01 \mathrm{~g}$, and (c) $0.02 \mathrm{~g} \mathrm{MWCNT.} \mathrm{At} \mathrm{the}$ end, the $\left(V_{\mathrm{oc}}\right)$ data slightly increased back to $0.65 \mathrm{~V}$ for sample (d) 0.03 g MWCNT. Short-circuit photocurrent density $\left(J_{\mathrm{sc}}\right)$ data for sample (a) $0.00 \mathrm{~g}$ is $7.60 \mathrm{mAcm}^{-2}$. The data for samples (b) $0.01 \mathrm{~g}$ and (c) $0.02 \mathrm{~g}$ decreased from $7.25 \mathrm{mAcm}^{-2}$ to $8.11 \mathrm{mAcm}^{-2}$. However, data for sample (d) $0.03 \mathrm{~g}$ increased rather large about $19 \%$ from sample (c) $0.02 \mathrm{~g}$ from $8.11 \mathrm{mAcm}^{-2}$ to $9.42 \mathrm{mAcm}^{-2}$ successively. The fill factor percentage data for (a) $0.00 \mathrm{~g}$, (b) $0.01 \mathrm{~g}$, (c) $0.02 \mathrm{~g}$, and (d) $0.03 \mathrm{~g} \mathrm{MWCNT}$ are 38\%, 43\%, 47\%, and $45 \%$ in that order. An increase in gas values implied enhanced electron transfer in DSSC [26]. The $V_{\mathrm{oc}}$ and $J_{\mathrm{sc}}$ data gradually increased for sample (d) $0.03 \mathrm{~g}$, which might be attributed from enlargement of thin film porosity and alignment of MWCNT in the photoelectrode thin film. As referred to other researches [27], MWCNT particles might cause a significant change in efficiency via the fluctuation of the short-circuit photocurrent and the open-circuit voltage for the DSSC. Incorporating $\mathrm{MWCNT}$ into $\mathrm{TiO}_{2}$ nanoparticles electrode might also affect the quantity of dye adsorption and the $\mathrm{e}^{-} / \mathrm{h}^{+}$ recombination process in this dye-sensitized solar cell.

The efficiency data for samples (a) $0.00 \mathrm{~g}$, (b) $0.01 \mathrm{~g}$, (c) $0.02 \mathrm{~g}$, and (d) $0.03 \mathrm{~g} \mathrm{MWCNT}$ are $1.43 \%, 2.12 \%, 2.46 \%$, and $2.80 \%$, respectively. Sample (d) $0.03 \mathrm{~g}$ CNT gives the highest efficiency percentage $2.80 \%$ with $0.65 \mathrm{~V}\left(V_{\mathrm{oc}}\right), 9.42 \mathrm{mAcm}^{-2}$ $\left(J_{\mathrm{sc}}\right)$, and $45 \%$ fill factor. Table 4 demonstrates the solar cell performance trend. It showed that, with every additional MWCNT powder, the efficiency of the solar cell exponentially increased. The $\mathrm{MWCNT} / \mathrm{TiO}_{2}$ nanocomposite combination tends to improve the electrical conductivity of the photoelectrode and also helps to enhance the interconnectivity between the $\mathrm{TiO}_{2}$ and MWCNT nanoparticles, thus increasing the short-circuit current density and providing an alternative route for efficient electron transfer between the $\mathrm{TiO}_{2}$ nanoparticles. It shows that the MWCNT can operate as an electrochemical catalyst to improve the energy conversion efficiency of DSSC [28]. The overall light to electrical effectiveness of the dye-sensitized solar cell can be efficiently enhanced with every additional MWCNT added. By referring to another researcher [29], the advantages of adding MWCNT in the photoelectrode are that the MWCNT can absorb over almost the entire visible light spectrum and act as photo sensitizers, providing the $\mathrm{MWCNT} / \mathrm{TiO}_{2}$ nanocomposites with an electron transfer mechanism similar to that of DSSC based $\mathrm{TiO}_{2}$. As a result, the $\mathrm{MWCNT} / \mathrm{TiO}_{2}$ samples can transfer excited electrons from the MWCNT to the conduction band of $\mathrm{TiO}_{2}$ when illuminated with visible light, thereby increasing the photocurrent. Second, the conductivity of MWCNTs is superior to that of $\mathrm{TiO}_{2}$; therefore, we can expect a high transport rate of electrons in the $\mathrm{CNT} / \mathrm{TiO}_{2}$ composites.

However, the concentration of MWCNT should be maintained $\sim 0.03 \mathrm{~g}$ optimum MWCNT to avoid MWCNT agglomeration within the films. This is because higher concentration of MWCNT can cause light-harvesting competition between the dye and MWCNT particles. Thus, increases the charge transport resistance and consequently reduces the solar cell efficiency [30]. Besides, excess MWCNT may cause aggregation of $\mathrm{TiO}_{2}$ grains (as observed in the FESEM result), leading to a decrease amount of dye being adsorbed on the working electrode. In addition, as reported by another researcher [31], excessive amount of MWCNT may cause the working electrode to be less transparent, which leads to reduced efficiency of DSSCs. Furthermore, this condition will decrease the crystallinity of the $\mathrm{TiO}_{2}$ samples, thereby inhibiting the transport of electrons and increasing the probability of electron trapping by the crystal defects. Moreover, the shielding and scattering effects of excess MWCNT might have prevented the photo absorption of other visible light-active species. Nevertheless, the optimum amount of MWCNT needs to be considered for fabrication of $\mathrm{MWCNT} / \mathrm{TiO}_{2}$ working electrodes being used in DSSC applications.

\section{Conclusion}

The $\mathrm{MWCNT} / \mathrm{TiO}_{2}$ nanocomposite DSSC was successfully fabricated using sol-gel method and doctor-blade technique. The films were uniform and highly adherent. Photochemical and structural properties of the thin film were improved by incorporate MWCNT powder into $\mathrm{TiO}_{2}$ nanoparticles. The $0.03 \mathrm{~g}$ is the best and optimum concentration of CNT added to this research. Excessive amount of CNT may cause the working electrode to be less transparent, which leads to reduced efficiency of DSSC. FESEM morphological analysis indicated that the $\mathrm{TiO}_{2}$ and $\mathrm{MWCNT} / \mathrm{TiO}_{2}$ thin films were in compact alignment and highly porous with thickness around $14.88 \mu \mathrm{m}$ and $18.79 \mu \mathrm{m}$. HR-TEM inner structural analysis confirms that the thin film is composed of $\mathrm{TiO}_{2}$ nanoparticles that existed around the multiwalled carbon nanotube particle. The average thickness for MWCNT and $\mathrm{TiO}_{2}$ nanocomposite was about $17.71 \mathrm{~nm}$ and $3.91 \mathrm{~nm}$, respectively. AFM analysis proved that the roughness factor can significantly improve the photoelectrode performance in the solar cell. The AFM topography reveals a very compact and rough surface; the rms values of all films are in the range of $10-25 \mathrm{~nm}$. From $I-V$ analysis, the highest efficiency 
$(\eta)$ wassuccessfully obtained from sample (c) $0.03 \mathrm{~g}$ added MWCNT with $2.80 \%$ efficiency, $0.65 \mathrm{~V}$ open-circuit voltage $\left(V_{\mathrm{oc}}\right), 9.42 \mathrm{mAcm}^{-2}$ short-circuit photocurrent density $\left(J_{\mathrm{sc}}\right)$, and $45 \%$ fill factor (FF). This result indicated that the solar cell efficiency can be enhanced by adding optimum concentration of MWCNT into $\mathrm{TiO}_{2}$ photoelectrode solar cell.

\section{Conflict of Interests}

The authors declare that there is no conflict of interests regarding the publication of this paper.

\section{Acknowledgment}

The authors would like to thank the Laboratory of Photonic Institute of Microengineering and Nanoelectronic (IMEN), Universiti Kebangsaan Malaysia, for providing the facilities.

\section{References}

[1] J. Burschka, N. Pellet, S. J. Moon et al., "Sequential deposition as a route to high-performance perovskite-sensitized solar cells," Nature, vol. 499, pp. 316-319, 2013.

[2] G. N. Fursey, D. V. Novikov, G. A. Dyuzhev, A. V. Kotcheryzhenkov, and P. O. Vassiliev, "The field emission from carbon nanotubes," Applied Surface Science, vol. 215, no. 1-4, pp. 135140, 2003.

[3] M. L. Chen, F. J. Zhang, and W. C. Oh, "Synthesis, characterization, and photocatalytic analysis of $\mathrm{CNT} / \mathrm{TiO}_{2}$ composites derived from MWCNTs and titanium sources," New Carbon Materials, vol. 24, no. 2, pp. 159-166, 2009.

[4] H. Lin, F. Hao, C. F. Lin, J. B. Li, and N. Wang, "Highly catalytic active nanostructured Pt electrodes for dye-sensitized solar cells prepared by low temperature electrodeposition," Functional Materials Letters, vol. 4, no. 1, pp. 7-11, 2011.

[5] A. Chindaduang, T. Sawatsuk, W. Wongsukkab, C. Sae-Kung, G. Tumcharern, and S. Pratonetep, "Electron microscopy and optical spectroscopy analyses of carbon nanotube composite electrodes for dye-sensitized solar cells," Journal of Microscopy, vol. 22, pp. 23-25, 2008.

[6] S. Chaveanghong, S. M. Smith, J. Sudchanham, and T. Amornsakchai, "Enhancement of power conversion efficiency of dye-sensitized solar cells by using multi-walled carbon nanotubes/ $/ \mathrm{TiO}_{2}$ electrode," Journal of the Microscopy Society of Thailand, vol. 4, no. 1, pp. 36-40, 2011.

[7] K. M. Lee, C. W. Hu, H. W. Chen, and K. C. Ho, "Incorporating carbon nanotube in a low-temperature fabrication process for dye-sensitized $\mathrm{TiO}_{2}$ solar cells," Solar Energy Materials and Solar Cells, vol. 92, no. 12, pp. 1628-1633, 2008.

[8] C. Y. Yen, Y. F. Lin, S. H. Liao et al., "Preparation and properties of a carbon nanotube-based nanocomposite photoanode for dye-sensitized solar cells," Nanotechnology, vol. 19, no. 37, Article ID 375305, 2008.

[9] S. R. Jang, R. Vittal, and K. J. Kim, "Incorporation of functionalized single-wall carbon nanotubes in dye-sensitized $\mathrm{TiO}_{2}$ solar cells," Langmuir, vol. 20, no. 22, pp. 9807-9810, 2004.

[10] T. Y. Lee, P. S. Alegaonkar, and J. B. Yoo, "Fabrication of dye sensitized solar cell using $\mathrm{TiO}_{2}$ coated carbon nanotubes," Thin Solid Films, vol. 515, no. 12, pp. 5131-5135, 2007.
[11] Y. Wang, Y. Tan, B. Liu, and B. Liu, "Dual-function layer of mesoporous structure anatase $\mathrm{TiO}_{2}$ for high performance dyesensitized solar cells," Functional Materials Letters, vol. 5, no. 1, Article ID 12500178, 2012.

[12] K. M. Lee, C. W. Hu, H. W. Chen, and K. C. Ho, "Incorporating carbon nanotube in a low-temperature fabrication process for dye-sensitized $\mathrm{TiO}_{2}$ solar cells," Solar Energy Materials and Solar Cells, vol. 92, no. 12, pp. 1628-1633, 2008.

[13] Y. Ao, J. Xu, D. Fu, X. Shen, and C. Yuan, "Low temperature preparation of anatase $\mathrm{TiO}_{2}$-coated activated carbon," Colloids and Surfaces A, vol. 312, no. 2-3, pp. 125-130, 2008.

[14] H. Abdullah, M. Z. Razali, S. Shaari, and M. R. Taha, "Enhancement of dye-sensitised solar cell efficiency using carbon nanotube/ $/ \mathrm{TiO}_{2}$ nanocomposite thin film at various annealing temperature," Electronic Materials Letters, 2013.

[15] T. Y. Lee, P. S. Alegaonkar, and J. B. Yoo, "Fabrication of dye sensitized solar cell using $\mathrm{TiO}_{2}$ coated carbon nanotubes," Thin Solid Films, vol. 515, no. 12, pp. 5131-5135, 2007.

[16] H. Abdullah, A. Omar, M. A. Yarmo, S. Shaari, and M. R. Taha, "Structural and morphological studies of zinc oxide incorporating single-walled carbon nanotubes as a nanocomposite thin film," Journal of Materials Science: Materials in Electronics, vol. 24, no. 9, pp. 3603-3610, 2013.

[17] A. Omar, H. Abdullah, S. Shaari, and M. R. Taha, "Characterization of zinc oxide dye-sensitized solar cell incorporation with single-walled carbon nanotubes," Journal of Materials Research, vol. 28, no. 13, pp. 1-8, 2013.

[18] J. Yu, T. Ma, and S. Liu, "Enhanced photocatalytic activity of mesoporous $\mathrm{TiO}_{2}$ aggregates by embedding carbon nanotubes as electron-transfer channel," Physical Chemistry Chemical Physics, vol. 13, no. 8, pp. 3491-3501, 2011.

[19] G. Xue, Y. Guo, T. Yu et al., "Degradation mechanisms investigation for long-term thermal stability of dye-sensitized solar cells," International Journal of Electrochemical Science, vol. 7, no. 2, pp. 1496-1511, 2012.

[20] E. R. Morales, N. R. Mathews, D. Reyes-Coronado et al., "Physical properties of the CNT: $\mathrm{TiO}_{2}$ thin films prepared by sol-gel dip coating," Solar Energy, vol. 86, no. 4, pp. 1037-1044, 2012.

[21] W. Zhou, K. Pan, Y. Qu et al., "Photodegradation of organic contamination in wastewaters by bonding $\mathrm{TiO}_{2} /$ single-walled carbon nanotube composites with enhanced photocatalytic activity," Chemosphere, vol. 81, no. 5, pp. 555-561, 2010.

[22] C. Y. Yen, Y. F. Lin, S. H. Liao et al., "Preparation and properties of a carbon nanotube-based nanocomposite photoanode for dye-sensitized solar cells," Nanotechnology, vol. 19, no. 37, Article ID 375305, 2008.

[23] S. Uk Lee, W. Seok Choi, and B. Hong, "A comparative study of dye-sensitized solar cells added carbon nanotubes to electrolyte and counter electrodes," Solar Energy Materials and Solar Cells, vol. 94, no. 4, pp. 680-685, 2010.

[24] N. P. Ariyanto, H. Abdullah, and N. S. A. Ghani, "Surface morphology characterisation of Sn-doped $\mathrm{ZnO}$ films for antireflective coating," Materials Research Innovations, vol. 13, no. 3, pp. 157-160, 2009.

[25] N. Ikeda and T. Miyasaka, "Plastic and solid-state dye-sensitized solar cells incorporating single-wall carbon nanotubes," Chemistry Letters, vol. 36, no. 3, pp. 466-467, 2007.

[26] K. M. Lee, C. W. Hu, H. W. Chen, and K. C. Ho, "Incorporating carbon nanotube in a low-temperature fabrication process for dye-sensitized $\mathrm{TiO}_{2}$ solar cells," Solar Energy Materials and Solar Cells, vol. 92, no. 12, pp. 1628-1633, 2008. 
[27] W. Feng, Y. Feng, Z. Wu, A. Fujii, M. Ozaki, and K. Yoshino, "Optical and electrical characterizations of nanocomposite film of titania adsorbed onto oxidized multiwalled carbon nanotubes," Journal of Physics Condensed Matter, vol. 17, no. 27, pp. 4361-4368, 2005.

[28] B. Munkhbayar, S. Hwang, J. Kim et al., "Photovoltaic performance of dye-sensitized solar cells with various MWCNT counter electrode structures produced by different coating methods," Electrochimica Acta, vol. 80, pp. 100-107, 2012.

[29] F. J. Zhang, M. L. Chen, and W. C. Oh, "Fabrication and electrophotolysis property of carbon nanotubes/titanium composite photocatalysts for methylene blue," Bulletin of the Korean Chemical Society, vol. 30, no. 8, pp. 1798-1804, 2009.

[30] J. Yu, J. Fan, and B. Cheng, "Dye-sensitized solar cells based on anatase $\mathrm{TiO}_{2}$ hollow spheres/carbon nanotube composite films," Journal of Power Sources, vol. 196, no. 18, pp. 7891-7898, 2011.

[31] S. Chaveanghong, S. M. Smith, J. Sudchanham, and T. Amornsakchai, "Enhancement of power conversion efficiency of dye-sensitized solar cells by using multi-walled carbon nanotubes $/ \mathrm{TiO}_{2}$ electrode," Journal of the Microscopy Society of Thailand, vol. 4, no. 1, pp. 36-40, 2011. 

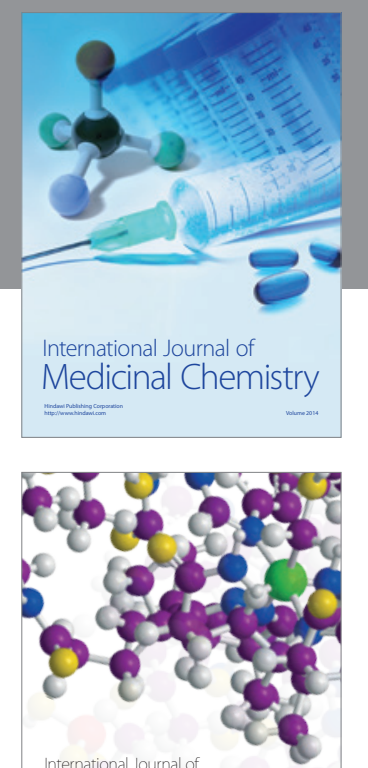

\section{Carbohydrate} Chemistry

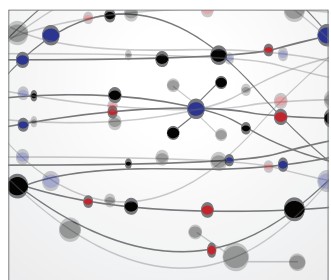

The Scientific World Journal
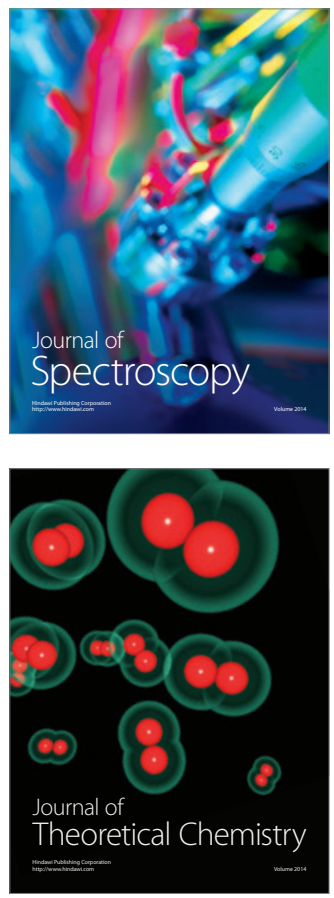
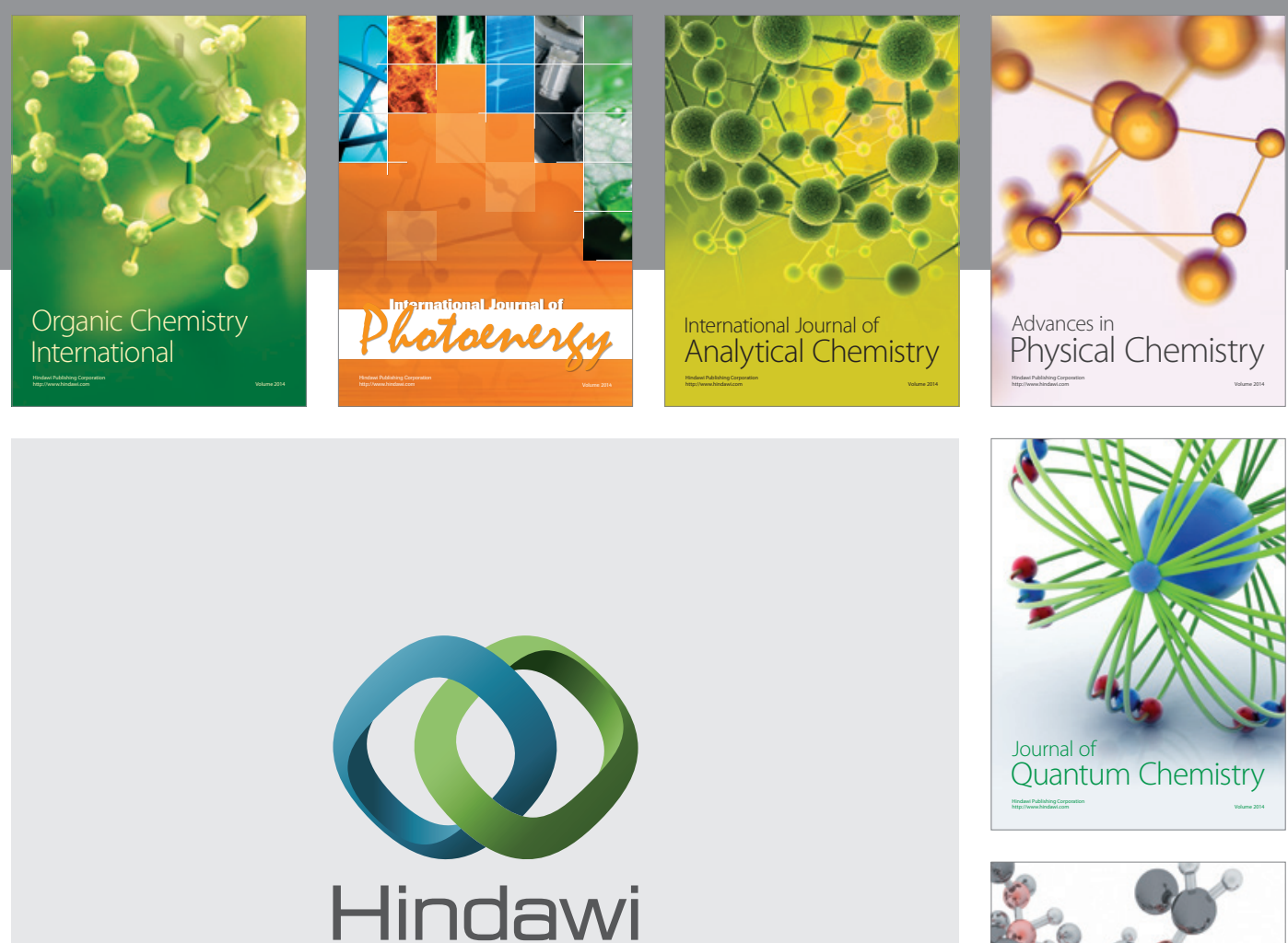

Submit your manuscripts at

http://www.hindawi.com

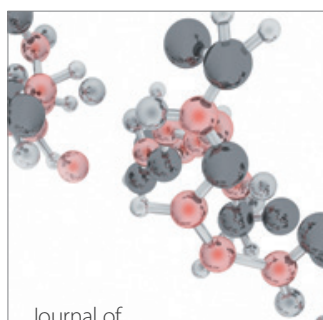

Analytical Methods

in Chemistry

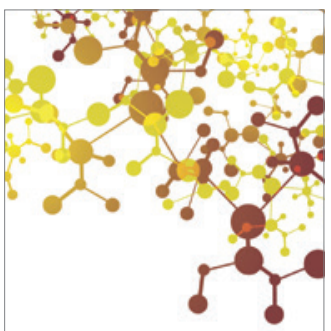

Journal of

Applied Chemistry

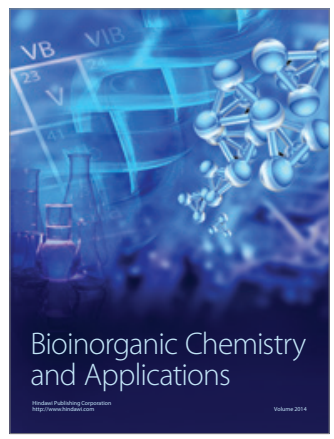

Inorganic Chemistry
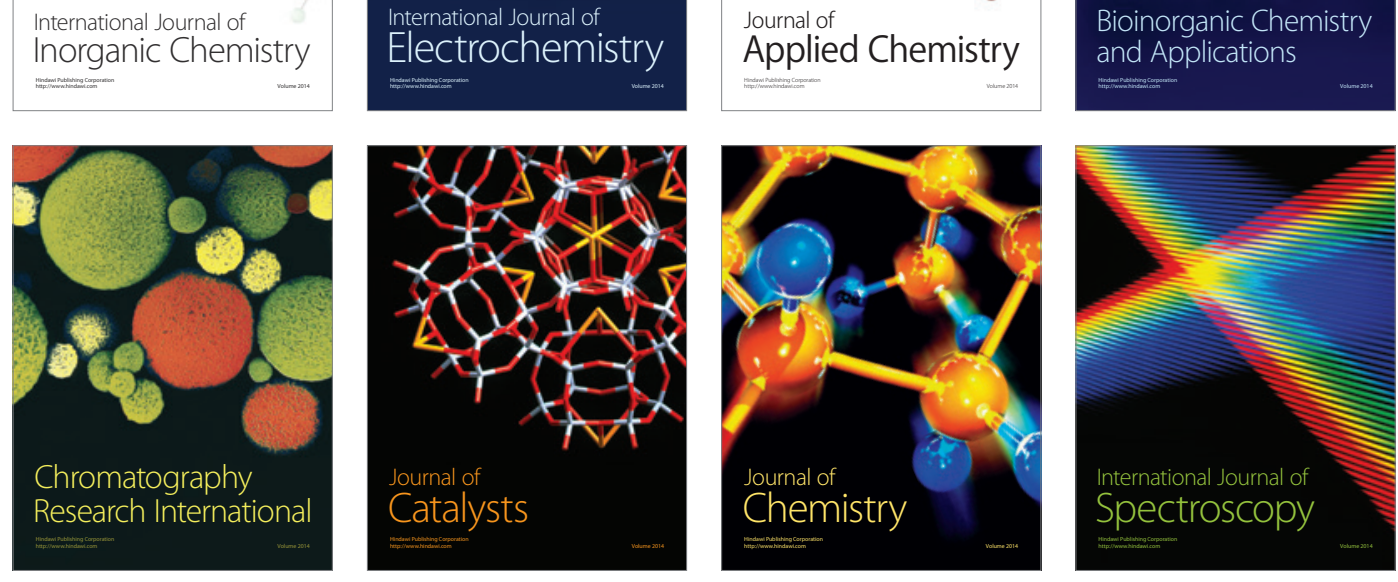